\title{
Vegetation Pattern and Heavy Metal Accumulation at a Mine Tailing at Gyöngyösoroszi, Hungary
}

János Tamás and Elza Kovács*

Department of Water and Environmental Management, Centre of Agricultural Sciences, University of Debrecen, H-4015 Debrecen, P.O. Box 10, Hungary. Fax: 36-52-508456.

E-mail: ekovacs@gisserver1.date.hu

* Author for correspondence and reprint requests

Z. Naturforsch. 60 c, 362-367 (2005)

Vegetation at an abandoned heavy metal bearing mine tailing may have multifunctional roles such as modification of water balance, erosion control and landscape rehabilitation. Research on the vegetation of mine tailings can provide useful information on tolerance, accumulation and translocation properties of species potentially applicable at moderately contaminated sites. Analyses of the relationship between heavy metal content $(\mathrm{Pb}, \mathrm{Zn}$ and $\mathrm{Cu}$ ) and vegetation in a mine tailing were carried out. These analyses included: (1) spatial analysis of relationship among heavy metal distribution, $\mathrm{pH}$ and vegetation patterns, and (2) analysis of heavy metal accumulation and translocation in some plant species. Presence of vegetation was found to be significantly dependent on $\mathrm{pH}$ value, which confirms that phytotoxicity is a function of element concentration in solution, which is primarily controlled by $\mathrm{pH}$ value in mine tailings. Among the most abundant plant species, dewberry (Rubus caesius), vipersbugloss (Echium vulgare), scarlet pimpernel (Anagallis arvensis) and narrowleaf plantain (Plantago lanceolata) accumulate significant amounts of $\mathrm{Pb}, \mathrm{Cu}$ and $\mathrm{Zn}$, while in the case of annual bluegrass (Pоа аппиа) only $\mathrm{Pb}$ can be measured in elevated contents. Considering the translocation features, scarlet pimpernel, narrowleaf plantain, and dewberry accumulate heavy metals primarily in their roots, while heavy metal concentration in vipersbugloss and annual bluegrass is higher in the shoots.

Key words: Heavy Metal, Mine Tailing, Vegetation

\section{Introduction}

Risk assessment and evaluation of recultivation technologies of sites where contaminants originate from mining activity and mining waste disposal are considered specific areas (Scokart et al., 1983). For recultivation of mine tailings, taking both economical and technological feasibilities into consideration, phytoremediation has been widely studied (Cunningham et al., 1995; Schnoor and Dee, 1997; Prasad and Freitas, 1999; Simon et al., 2002). Phytoremediation technology seems to be applicable, since these sites have relatively low environmental impact. That is, contaminants do not show high dispersion resulting in hazard of surface and subsurface water pollution as well as human health risk through land use. However, revegetation of mine tailings may be difficult due to high salt concentration, heavy metals, insufficiently available nutrients, and poor water management (Johnson et al., 1977; Vangronsveld et al., 1994, 1996).

The role of vegetation is significant in changing water balance, erosion control, and landscape (Kamnev and van der Lelie, 2000). Phytoremedia- tion of mine tailings is an efficient method for erosion and runoff control as well as to reduce heavy metal transport through infiltration (Palmer, 1992; Vangronsveld et al., 1995; Zhu et al., 1999). Research on natural vegetation of mining areas having high metal content provides information relevant to risk assessment and remediation planning, and results are also important from an ecological point of view (Thompson and Proctor, 1983; Leita and De Nobili, 1989; Wenzel and Jockwer, 1999; Fernandez-Turiel et al., 2001; Galicz et al., 2002; Hayes and Traina, 1998).

Primary vegetation found in mine tailings is generally sparse, with few species. However, the presence of species tolerating extreme conditions results in increasing organic content and improves soil quality (Sieghardt, 1989). Considering the colonisation by higher plants, Connell and Slatyer (1977) suggested three succession models based on facilitation, tolerance and inhibition. According to Ernst (1989), the first one can be adapted to mine tailings.

Vegetation pattern and species distribution of a mine tailing correlate more strongly with $\mathrm{pH}$ value 
and cation exchange capacity than total heavy metal concentration (Wickland, 1989). However, heavy metals have a significant role in that vegetation and succession of contaminated sites differs from that of uncontaminated areas (Brümmer et al., 1986).

This study summarizes the results of the spatial analysis of relationship among heavy metal distribution, $\mathrm{pH}$ value and vegetation patterns based on field measurements at an abandoned mine tailing, and that of the analysis of heavy metal accumulation and translocation in some local plant species.

\section{Materials and Methods}

The relationship between vegetation pattern, heavy metal distribution and $\mathrm{pH}$ value was analysed at the Gyöngyösoroszi mining site in North Hungary, where $\mathrm{Pb}$ and $\mathrm{Zn}$ were mined from 1952 to 1986. At the site a qualitative environmental impact assessment was carried out by Horváth and Gruiz (1996). Ódor et al. (1998) conducted geological and geochemical investigations and a preliminary analysis of the natural vegetation was carried out by Galicz et al. (2002).

The factors that potentially determine the presence/absence of vegetation were analysed at a $5 \mathrm{~m} \times 16 \mathrm{~m}$ area selected on the basis of previous studies, where plant species identification and mining waste sampling were carried out systematically in a $50 \mathrm{~cm} \times 50 \mathrm{~cm}$ grid. Coenological survey was carried out in September 2001-2003, and relationships between heavy metal content and vegetation were analysed. The heavy metal accumulation and translocation features were characterised for 5-5 individuals of the most abundant plant species: Rubus ceasius, Echium vulgare, Poa annua, Plantago lanceolata and Anagallis arvensis. The element contents of plant roots and shoots for dry material were measured with ICP-OES after wet $\mathrm{HNO}_{3} / \mathrm{H}_{2} \mathrm{O}_{2}$ digestion. Heavy metal contents $(\mathrm{Zn}$, $\mathrm{Pb}$ and $\mathrm{Cu}$ ) were measured with a field portable XRF spectrometer (NITON XL700) calibrated with respect to the matrix effect by comparing data to ICP results and normalizing to water content. Measurements were carried out for ground and air-dried samples according to the US EPA 6200 method worked out for the FPXRF technique. The $\mathrm{pH}$ value of each sample was determined potentiometrically.

Geo-statistical and spatial pattern analyses were carried out using the software Idrisi 32 and the Mann-Whitney-Wilcoxon test was used to evalu- ate the dependence of presence/absence of vegetation on heavy metal concentration and $\mathrm{pH}$ value.

\section{Results and Conclusions}

Vegetation of the mine tailing

Most plant species identified at the mine tailing favour moderately dry climate and the most abundant species prefer neutral or moderately alkaline soils. Plants found at the study area in September 2001-2003 are listed in Table I. Considering the natural protection category, the dominant species indicate degradation, they are weeds and resistant ones, while pioneers and accompanying species are less abundant. The small number of association-forming species indicates that stable associations have not yet appeared. Neither the R nor the W spectrum show trends (data not shown) indicating that soil characteristics and microclimate did not change significantly during 3 years.

\section{Spatial relations between vegetation, heavy metal concentration and $\mathrm{pH}$ value}

Spatial pattern analysis of vegetation, heavy metal content and $\mathrm{pH}$ value may reveal the factors that determine plant growth at mining areas. There is no significant correlation between total heavy metal content and $\mathrm{pH}$ value in the case of $\mathrm{Pb}$, while for $\mathrm{Zn}$ and $\mathrm{Cu}$ the Spearman coefficients are $0.546(P<0.01)$ and $0.374(P<0.01)$, respectively.

The Mann-Whitney-Wilcoxon probe shows that the spatial pattern of the vegetation does not vary with total heavy metal concentration. Probabilities of validity of $\mathrm{H0}(\mathrm{P})$ for $\mathrm{Cu}, \mathrm{Zn}, \mathrm{Pb}$ and $\mathrm{pH}$ are $0.749,0.263,0.012$, and 0.000 , respectively. Thus, median values for total heavy metal concentrations measured at areas having vegetation cover and for those where vegetation is absent do not differ significantly. However, the presence of vegetation is significantly dependent on the $\mathrm{pH}$ value of the soil.

Linear multistep regression analyses also confirm that the $\mathrm{pH}$ value is the determining factor with respect to vegetation cover and show that the correlation is significant at $P<0.01$ (Table II).

Considering the number of species, statistical analyses show that the total heavy metal contents are also not determinative, but the $\mathrm{pH}$ value has a significant effect $(P<0.01)$ (Table II). At the same time, correlation coefficients are rather low and indicate a poor relationship. Phytotoxicity is a func- 
Table I. Identified species at a mine tailing at Gyöngyösoroszi, Hungary between 2001 and 2003.

\begin{tabular}{|c|c|c|c|c|c|c|c|}
\hline Species & $\mathrm{T}$ & W & $\mathrm{R}$ & TVK & 2001 & 2002 & 2003 \\
\hline Agropyron repens & 5 & 3 & 0 & GY & & & $\mathrm{X}$ \\
\hline Anagallis arvensis & $6 a$ & 3 & 4 & GY & $\mathrm{X}$ & $\mathrm{X}$ & \\
\hline Arrheanathelum elatius & $5 \mathrm{a}$ & 5 & 4 & $\mathrm{TZ}$ & & $\mathrm{X}$ & \\
\hline Artemisia absinthium & 6 & 3 & 4 & GY & & $\mathrm{X}$ & \\
\hline Artemisia vulgaris & 5 & 4 & 0 & GY & & $\mathrm{X}$ & $\mathrm{X}$ \\
\hline Betula pendula & 3 & 4 & 0 & $\mathrm{E}$ & & $\mathrm{X}$ & $\mathrm{X}$ \\
\hline Carduus acanthoides & $6 \mathrm{a}$ & 3 & 0 & GY & & $\mathrm{X}$ & \\
\hline Carex hirta & $5 \mathrm{a}$ & 7 & 0 & GY & & & $\mathrm{X}$ \\
\hline Centaurea jacea & $5 a$ & 6 & 0 & $\mathrm{TZ}$ & & $\mathrm{X}$ & $\mathrm{X}$ \\
\hline Cerastium semidecandrum & $6 \mathrm{a}$ & 3 & 0 & TP & & $\mathrm{X}$ & $\mathrm{X}$ \\
\hline Cirsium arvense & 5 & 4 & 0 & GY & $X$ & $\mathrm{X}$ & $\mathrm{X}$ \\
\hline Conium maculatum & $5 \mathrm{a}$ & 5 & 3 & GY & $\mathrm{X}$ & $\mathrm{X}$ & \\
\hline Convolvulus arvensis & 0 & 3 & 4 & GY & & $\mathrm{X}$ & $\mathrm{X}$ \\
\hline Dactylis glomerata & $5 a$ & 6 & 4 & $\mathrm{TZ}$ & & & $\mathrm{X}$ \\
\hline Daucus carota & $5 \mathrm{a}$ & 2 & 5 & $\mathrm{TZ}$ & & & $\mathrm{X}$ \\
\hline Echium vulgare & $6 a$ & 3 & 0 & TP & $\mathrm{X}$ & $\mathrm{X}$ & $\mathrm{X}$ \\
\hline Euphorbia cyparissias & $5 \mathrm{k}$ & 3 & 4 & GY & & $\mathrm{X}$ & $X$ \\
\hline Euphorbia seguieriana & $6 \mathrm{k}$ & 1 & 4 & $\mathrm{~K}$ & $\mathrm{X}$ & & \\
\hline Festuca heterophylla & $5 \mathrm{a}$ & 4 & 3 & $\mathrm{~K}$ & $\mathrm{X}$ & $\mathrm{X}$ & $\mathrm{X}$ \\
\hline Festuca pratensis & 5 & 7 & 4 & $\mathrm{E}$ & $X$ & $\mathrm{X}$ & $\mathrm{X}$ \\
\hline Fragaria vesca & 5 & 5 & 3 & $\mathrm{~K}$ & $X$ & & \\
\hline Lotus corniculatus & $5 \mathrm{a}$ & 4 & 0 & $\mathrm{TZ}$ & & & $\mathrm{X}$ \\
\hline Lupinus albus & & & & & $\mathrm{X}$ & & \\
\hline Medicago falcata & $6 \mathrm{k}$ & 3 & 4 & TZ & & & $\mathrm{X}$ \\
\hline Medicago minima & 7 & 2 & 4 & $\mathrm{TP}$ & & $\mathrm{X}$ & $\mathrm{X}$ \\
\hline Melandrium album & 5 & 4 & 0 & $\mathrm{G}$ & $X$ & $X$ & $\mathrm{X}$ \\
\hline Plantago altissima & $5 \mathrm{a}$ & 7 & 4 & $\mathrm{TZ}$ & & $X$ & \\
\hline Plantago lanceolata & $5 \mathrm{a}$ & 4 & 0 & $\mathrm{TZ}(\mathrm{K})$ & $X$ & $\mathrm{X}$ & $\mathrm{X}$ \\
\hline Plantago major & $5 \mathrm{a}$ & 7 & 0 & GY & & $X$ & $\mathrm{X}$ \\
\hline Plantago media & 5 & 5 & 0 & $\mathrm{TZ}$ & $\mathrm{X}$ & $\mathrm{X}$ & \\
\hline Роа аппиа & 0 & 8 & 0 & GY & $\mathrm{X}$ & $\mathrm{X}$ & $X$ \\
\hline Poa nemoralis & 5 & 4 & 3 & $\mathrm{TZ}$ & & & $\mathrm{X}$ \\
\hline Poa pratensis & 5 & 6 & 0 & $\mathrm{~K}$ & $\mathrm{X}$ & $\mathrm{X}$ & $X$ \\
\hline Polygonum aviculare & 0 & 4 & 3 & GY & & $\mathrm{X}$ & $\mathrm{X}$ \\
\hline Polygonum lapatipholium & 0 & 9 & 3 & GY & $\mathrm{X}$ & & $\mathrm{X}$ \\
\hline Potentilla reptans & 0 & 6 & 3 & $\mathrm{TZ}$ & $\mathrm{X}$ & $\mathrm{X}$ & $\mathrm{X}$ \\
\hline Prunus spinosa & $5 a$ & 3 & 3 & $\mathrm{TZ}$ & $X$ & $\mathrm{X}$ & $\mathrm{X}$ \\
\hline Pulmonaria officinalis & $5 \mathrm{a}$ & 6 & 3 & $\mathrm{~K}$ & & $X$ & \\
\hline Robinia pseudo-acacia & 5 & 3 & 4 & GY & & $\mathrm{X}$ & $\mathrm{X}$ \\
\hline Rubus ceasius & 5 & 8 & 4 & $\mathrm{TZ}$ & $\mathrm{X}$ & $\mathrm{X}$ & $\mathrm{X}$ \\
\hline Silene vulgaris & 5 & 3 & 4 & $\mathrm{~K}$ & & $\mathrm{X}$ & $X$ \\
\hline Stellaria graminea & 5 & 4 & 3 & $\mathrm{TZ}$ & & $\mathrm{X}$ & $\mathrm{X}$ \\
\hline Stellaria media & 0 & 5 & 0 & GY & $\mathrm{X}$ & & \\
\hline Taraxacum officinale & 0 & 5 & 0 & GY & $\mathrm{X}$ & $\mathrm{X}$ & $\mathrm{X}$ \\
\hline Trifolium pratense & 5 & 6 & 3 & $\mathrm{TZ}$ & & $\mathrm{X}$ & $\mathrm{X}$ \\
\hline Trifolium repens & & & & & & $X$ & \\
\hline
\end{tabular}

$\mathrm{T}$, heat management-climate (0: uncharacteristic, 3: taiga, 5: deciduous forest, 6 : submediterranean deciduous forest, 7: mediterranean atlantic evergreen forest, a: atlantic, k: continental); W, water management (1: very dry, 2: dry, 3: moderately dry, 4: moderately fresh, 5: fresh, 6: moderately wet, 7: wet, 8: moderately watery, 9: watery); R, soil reaction $-\mathrm{pH}$ (0: uncharacteristic, 3: nearly neutral, 4: moderately basic, calcareous, 5: calcareous, basic); TVK, natural protection category (TZ: resistant, K: accompanying, GY: weed, G: crop, E: association composing, TP: pioneer).

tion of element concentration in solution, which is primarily controlled by $\mathrm{pH}$. However, the $\mathrm{pH}$ value also determines several physiologically important and essential soil parameters in addition to the potentially bio-available metal concentrations.

\section{Heavy metal uptake at mine tailings}

Heavy metal contents measured in plant shoots and roots were compared to contents characteristic in the environment of the rhizosphere. Heavy 
Table II: Results of regression analyses for vegetation pattern-heavy metal distribution-pH relationship and number of species-heavy metal distribution-pH relationship.

\begin{tabular}{|c|c|c|c|c|c|c|}
\hline & $n$ & Value & $\begin{array}{l}\text { Standard } \\
\text { error }\end{array}$ & $\mathrm{T}$ & $\mathrm{P}$ & $\mathrm{r}$ \\
\hline \multicolumn{7}{|c|}{$y($ presence of vegetation $)=a[\mathrm{~Pb}]+b[\mathrm{Zn}]+c[\mathrm{Cu}]+\mathrm{d} \mathrm{pH}+e$} \\
\hline $\begin{array}{l}\text { Model } 1 \\
a \\
b \\
c \\
d \\
e\end{array}$ & 312 & $\begin{array}{l}-0.000015 \\
-0.000005 \\
-0.0000007 \\
-0.156 \\
-0.083\end{array}$ & $\begin{array}{l}0.000008 \\
0.000003 \\
0.000013 \\
0.023 \\
0.134\end{array}$ & $\begin{array}{r}-1.80 \\
-1.80 \\
-0.05 \\
6.84 \\
-0.62\end{array}$ & $\begin{array}{l}0.073 \\
0.074 \\
0.956 \\
0.000 \\
0.538\end{array}$ & 0.431 \\
\hline $\begin{array}{l}\text { Model } 2 \\
d \\
e\end{array}$ & 316 & $\begin{array}{c}0.13 \\
-0.086\end{array}$ & $\begin{array}{l}0.02 \\
0.12\end{array}$ & $\begin{array}{r}6.53 \\
-0.72\end{array}$ & $\begin{array}{l}0.000 \\
0.474\end{array}$ & 0.439 \\
\hline \multicolumn{7}{|c|}{$y($ number of species $)=a[\mathrm{~Pb}]+b[\mathrm{Zn}]+c[\mathrm{Cu}]+d \mathrm{pH}+e$} \\
\hline $\begin{array}{l}\text { Model } 1 \\
a \\
b \\
c \\
d \\
e\end{array}$ & 312 & $\begin{array}{c}-0.00001 \\
-0.00002 \\
-0.000019 \\
0.399 \\
-0.68\end{array}$ & $\begin{array}{l}0.00002 \\
0.000008 \\
0.000036 \\
0.06 \\
0.36\end{array}$ & $\begin{array}{r}-0.47 \\
-2.59 \\
-0.53 \\
6.54 \\
-1.90\end{array}$ & $\begin{array}{l}0.637 \\
0.010 \\
0.596 \\
0.000 \\
0.058\end{array}$ & 0.130 \\
\hline $\begin{array}{l}\text { Model } 2 \\
d \\
e\end{array}$ & 316 & $\begin{array}{r}0.288 \\
-0.412\end{array}$ & $\begin{array}{l}0.053 \\
0.321\end{array}$ & $\begin{array}{r}5.39 \\
-1.28\end{array}$ & $\begin{array}{l}0.000 \\
0.201\end{array}$ & 0.085 \\
\hline
\end{tabular}

Table III: Accumulated heavy metal contents for the examined species $(N=5)\left(\mathrm{mg} \mathrm{kg} \mathrm{kg}^{-1}\right.$ dry material).

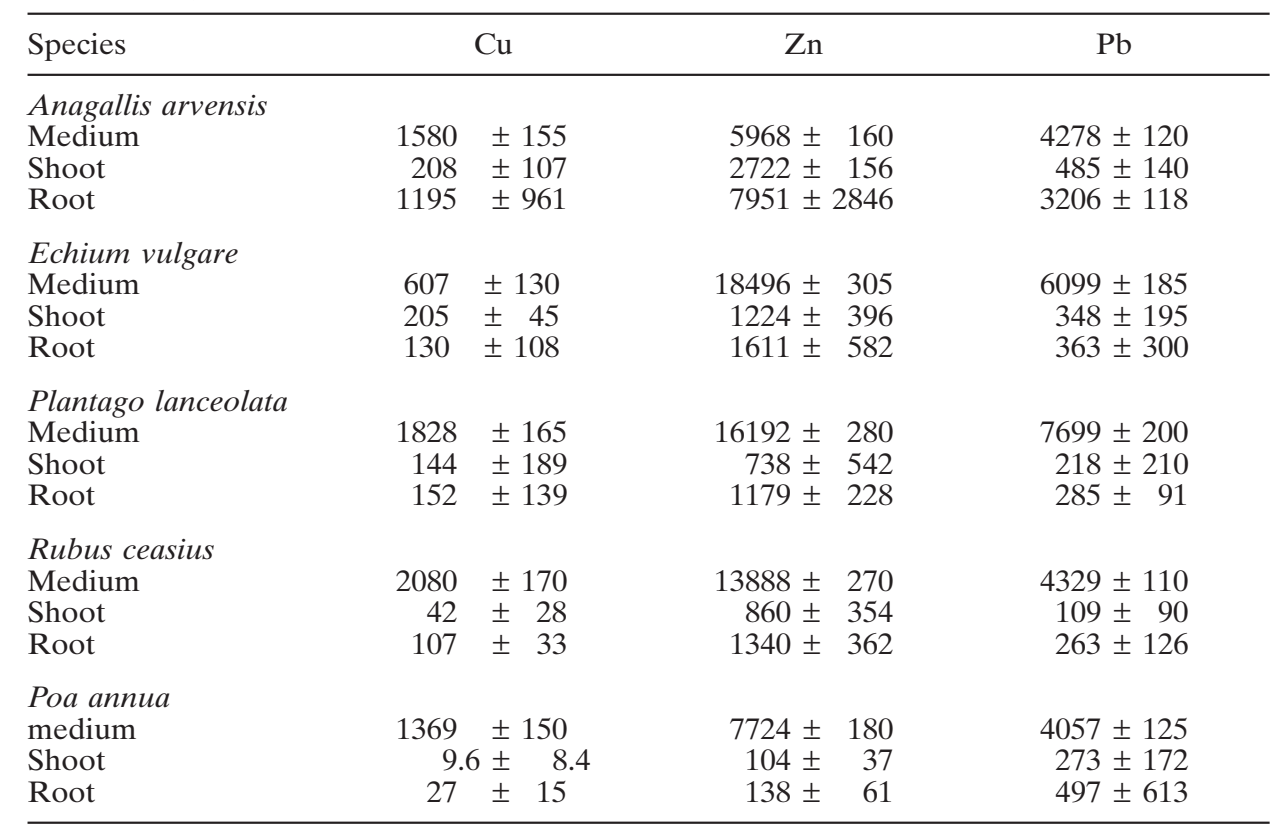


metal tolerance in plants varies with each species and heavy metal. Based on their accumulation features, our results show that the most abundant plants are highly metal tolerant, and accumulate heavy metals in considerable amounts (Table III). This observation is important when a phytoextraction technology is considered. The most abundant species found at the mining area have high $\mathrm{Pb}, \mathrm{Zn}$ and $\mathrm{Cu}$ accumulating ability, with the exception of annual bluegrass, which accumulates only $\mathrm{Pb}$ in large amounts and excludes $\mathrm{Zn}$ and $\mathrm{Cu}$. These results are in agreement with those of Djingova et al.
(1993). Scarlet pimpernel, narrowleaf plantain and dewberry were found to accumulate heavy metals primarily in their roots, while vipersbugloss accumulates $\mathrm{Pb}$ and $\mathrm{Cu}$ in the shoots.

\section{Acknowledgements}

Research was carried out as a part of the project BIO-02453/2000 financed by the Ministry of Education, Hungary. The authors thank the staff at the Department of Water and Environmental Management, University of Debrecen, Hungary for their help in the research.
Brümmer G. W., Gerth J., and Herms U. (1986), Heavy metal species, mobility and bioavailability in soils. $\mathrm{Z}$. Pfl. Bodenk. 149, 382-398.

Connell J. H. and Slatyer R. O. (1977), Mechanisms of succession in natural communities and their role in community stability and organisation. Am. Nat. 111, 1119-1144.

Cunningham S. D., Berti W. R., and Huang J. W. (1995), Phytoremediation of contaminated soils. Tibtech. 13, 393-397.

Djingova R., Kuleff I., and Andreev N. (1993), Comparison of the ability of several vascular plants to reflect environmental pollution. Chemosphere 27, 1385-1396.

Ernst W. H. O. (1989), Mine vegetation in Europe. In: Heavy Metal Tolerance in Plants: Evolutionary Aspects (Shaw A. J., ed.). CRC, Boca Raton, FL, USA, pp. $21-37$.

Fernandez-Turiel J. L., Acenolaza P., Medina M. E., Llorens J. F., and Sardi F. (2001), Assessment of a smelter impact area using surface soils and plants. Env. Geochem. Health 23, 65-78.

Galicz É., Tóth A., Lakatos G., Paksi V., and Tamás J. (2002), Feasibility study of phytoremediation via analyses of the natural vegetation. In: Proc. SEGH Twentieth Eur. Conf. Heavy Metal Contamination and the Quality of Life, Debrecen, Hungary, p. 53.

Hayes K. F. and Traina S. J. (1998), Metal ion speciation and its significance in ecosystem health. In: Soil Chemistry and Ecosystem Health (Huang P. M., Adriano D. C., Logan T. J., and Checkai R. T., eds.). SSSA Special Publication 52, Madison, USA, pp. 45-84.

Horváth B. and Gruiz K. (1996), Impact of metalliferous ore mining activity on the environment in Gyongyosoroszi, Hungary. Sci. Total. Environ. 184, 215-227.

Johnson M. S., McNeilly T., and Putwain P. D. (1977), Revegetation of metalliferous mine spoil contaminated by lead and zinc. Env. Pollut. 12, 261-277.
Kamnev A. A. and van der Lelie D. (2000), Chemical and biological parameters as tools to evaluate and improve heavy metal phytoremediation. Bioscience Rep. 20, 239-258.

Leita L. and De Nobili, M. (1989), Anomalous contents of heavy metals in soils and vegetation of a mine area in S. W. Sardinia, Italy. Water Air Soil Pollut. 48, $423-433$.

Ódor L., Wanty R. B., Horváth I., and Fügedi U. (1998), Mobilization and attenuation of metals downstream from a base-metal mining site in the Mátra Mountains, northeastern Hungary. J. Geochem. Explor. 65, 47-60.

Palmer J. P. (1992), Environmental aspects of the reclamation of metalliferous mine sites. In: Minerals, Metals and Environment (Anthony M. T., ed.). Elsevier, London, pp. 467-479.

Prasad M. N. V. and Freitas H. M. O. (1999), Feasible biotechnological and bioremediation strategies for serpentine soils and mine spoils. J. Biotechnol. 2, $36-50$.

Schnoor J. L. and Dee P. E. (1997), Phytoremediation. Technology evaluation report, TE-98-01, Ground Water Remediation Technologies Analysis Center, Pittsburgh, USA, pp. 1-37.

Scokart P. O., Meeus-Verdinne K., and De Borger R. (1983), Mobility of heavy metals in polluted soils near zinc smelters. Water Air Soil. Pollut. 20, 451-463.

Sieghardt H. (1989), Heavy metal uptake and distribution in Silene vulgaris and Minuartia verna growing on mining dump material containing lead and zinc. Plant Soil 123, 107-111.

Simon L., Kovács B., and Gyóri Z. (2002), Phytostabilization of mine spoil with red fescue (Festuca rubra L.). In: Proc. SEGH Twentieth Eur. Conf. Heavy Metal Contamination and the Quality of Life, Debrecen, Hungary, p. 15. 
Thompson J. and Proctor J. (1983), Vegetation and soil factors on a heavy metal mine spoil heap. New Phytol. 94, 297-308.

Vangronsveld J., Colpaert J. V., and Van Tichelen K. K. (1994), Reclamation of a bare industrial area contaminated by non-ferrous metals: in situ metal immobilization and revegetation. Environ. Pollut. 87, 51-59.

Vangronsveld J., Sterckx J., Van Assche F., and Clijsters H. (1995), Rehabilitation studies on an old non-ferrous waste dumping ground: effect of revegetation and metal immobilization by beringite. J. Geochem. Explor. 52, 221-229.

Vangronsveld J., Colpaert J. V., and Van Tichelen K. K. (1996), Reclamation of a bare industrial area contami- nated by non-ferrous metals: Physico-chemical and biological evaluation of the durability of soil treatment and revegetation. Environ. Pollut. 94, 131-140. Wenzel W. W. and Jockwer F. (1999), Accumulation of heavy metals in plants grown on mineralised soils of the Austrian Alps. Environ. Pollut. 104, 145-155.

Wickland D. E. (1989), Vegetation of heavy metal contaminated soils in North America. In: Heavy Metal Tolerance in Plants: Evolutionary Aspects (Shaw A. J., ed.). CRC, Boca Raton, pp. 39-51.

Zhu D., Schwab A. P., and Banks M. K. (1999), Heavy metal leaching from mine tailings as affected by plants. J. Environ. Qual. 28, 1727-1732. 
Nachdruck - auch auszugsweise - nur mit schriftlicher Genehmigung des Verlages gestattet Satz und Druck: AZ Druck und Datentechnik GmbH, Kempten 